石油技術協会誌 第 41 巻 第 6 号 (昭和 51 年 11 月)

JOURNAL OF THE JAPANESE ASSOCIATION OF PETROLEUM TECHNOLOGISTS

VOL. 41, NO. 6 (November, 1976)

石油鉱床の技術が今後向うべき方向*

一大地震の防止と地震エネルギー有効利用への道—

細井弘**

石油鉱床技術が今後向らべき方向，といらようなこと を大上段に振りかぶって題名にかかげた観があるが，実 はここでは石油技術全般について述べようとしているの ではなく，題名にあげたように「石油鉱床技術」につい て述べるつもりなのである。

この「石油鉱床技術」といらのは私の勝手な呼び方で 世間には通用していないかも知れないが，この機会に私 としてはぜひこの呼称を提唱したい。私の分類では「石 油鉱床技術」とは地球物理学 - 地質学・油層工学等の地 下の石油鉱床とのものを取り扱ら技術の総称であって, 掘さくや生産施設等の他の技術と異なったカテゴリーと して取り上げたのである。なぜならば石油開発会社がま ず第 1 義的に挑戦しなければならぬ企業りスクは石油鉱 床から生れるリスクなので，当然石油鉱床とのものを解 明しようとする「石油鉱床技術」がリスクへ立ら向う石 油会社の支えになるべき使命を背負っているからであ る。

さて本題に戻ると，ここでは「層位封鎖」をこれから 探鉱して行く場合に地球物理学・地質学・油層工学の 3 者の技術，つまり石油鉱床技術の中での各部門の緊密な 結びつきがいかに大切かを述べ，そしてその意味での石 油鉱床技術の発展は「地震エネルギー有効利用への道」 に通ずる可能性があることを強調しょうと思うのであ る。

\section{1. 層位封鎖探鉱のために}

まず最初に層位封鎖といらタイプの油田がそんなに残 されているだろらかといら問題がある。たしかに今まで 発見された油田の $80 \%$ 以上は背斜構造による集油が主体 であり，層位封鎖とか断層封鎖とかいらタイプのトラッ プは副次的に発見された場合が多い。

それならば過去の発見率の示すように，層位封鎖によ る集油のチャンスは背斜によるそれよりも果してはるか に少数なのだろらか？ 私はそらとは断言できないと考

* 昭和 51 年 5 月 26 日, 石油技術協会第 41 回定時総会特別講演

** 海外石油開発株式会社
える。人間の行なった探鉱上の統計值と自然の分布状態 とを混同してはいけないと思う。なるほど20世紀の初め 以来，組織的なあるいは科学的な探鉱をつつけて来たよ らに見えるが，実はそれらのほとんどすべては背斜構造 を目標に行なって来たのである。そしてこれは現在もあ まり変りがない。

したがって米国国内や日本国内のように，探鉱密度が 高い地域といわれている所ですら試掘はほとんど背斜構 造に集中しており，含油地域の basinの中でも地層の単 斜地域や水平地域はかなり空白のまま残されている。し かも面積的にはこの空白地域の方が多いはずである。な ぜならば，1坑の試掘で確認や予想ができる範囲はそれ ほど広いものではないからである。

ではこの残された空白地域に果して他のトラップ形 式，例えば層位封鎖による集油のチャンスがあるかどう かが問題である。私はこれに対して大きな可能性がなき にしもあらずと考光ているが，これを示唆する1例を私 が経験したものから引用して述べて見たい。

それは中東カタール沖合に抢ける例である。同地域は 日本のカタール石油株式会社が約 $8,000 \mathrm{~km}^{2}$ の 沖 合地域 に利権を取得し，8坑の試掘を行ない，これらのうら数 坑から出油を見たが商業生産に至らず，探鉱作業に終止 符を打たざるを得なかった場所なのである。

ところで同地域（海域）を含みカタール国全体を見渡 すと，その領土の面積は海陸併せて約 $46,500 \mathrm{~km}^{2}$ あり, この中に散在する既存の主要 4 油田, つまり陸上デュカ ン油田および海上イデ・アル・シャルギ油田を含めて, これらの推定総回収量は 5 億〜 6 億 bbl であり, ほとん どジュラ紀のアラブ層から生産している。そしてこれと 比較するためにこれに直接境を接している東隣りのアブ ダビに眼を転じて見よう。アブダビ海域の中でアラブ層 貯留岩の分布する面積は約 $20,000 \mathrm{~km}^{2}$ である。つまりカ タールのそれの半分以下である。にもかかわらずウム・ シャイフその他の油田のアラブ層からの推定総回収量は ${ }_{+} 0$ 億 $\mathrm{bbl}$ 以上にもなるのである。

いい換えると, カタール領域では $1 \mathrm{~km}^{2}$ 当り僅か 12,000 
bbl の回収量であり，一方アブダビ海域では $1 \mathrm{~km}^{2}$ 当り 20万 bbl むの回収量になるのである。つまりアブダビ海 域はカタールよりる20倍近い高い密度を持っていること になる。これは回収量どうしの密度の比較であるが，同 じアラブ層の油層といらことでほぼ似たような回収率を 想定すれば，これは同時に原始埋蔵量の密度の比較にな るともいえよう。

重要なのは互いに隣接する地域の同一貯留岩の間でこ のような20:1に近いような埋蔵量の密度差を示している といらことである。集油の自然分布状態としてこれが真 実の姿なのであるらがいら疑問が湧くのである。

たしかに，地震探鈗の結果によればアブダビ海域の力 がはるかに背斜構造の数が多く，それらの構造規模もカ タールのものよりも平均して大きい。しかしカタール半 島先端部の構造は中東第 1 級の大規模なドーム構造であ りながら，多数の試掘の結果では水に満たされて㧍り集 油していない模様である。

とにかくペルシャ湾 (アラビア湾) のジュラ紀の堆 積盆地の規模は大きく，母岩としての堆積環境は実に uniform であって，アブダビとカタールの領域との間で 差異があったとは思えない。つまり石油生成の根源物質 の堆積密度と熟成作用に対する条件は両地域とも注とん ぞ同じであると見た方が良い。母岩のポテンシテルとし ては同一地域と考光られる。

それならば，大部分の石油はアラブ層貯留岩の中での 第 2 次移動（水平移動）に上り東方アブダビ地域へ移動 していったのであろらか？こ机は非常に無理な想像で ある。なぜかといらと，地質データの積み重ねによって 解釈しても，地史的に見て石油が一方的にアブダビへ大 移動を起したという証拠はないからである。それに加党 て, アラブ層は石网岩貯留岩である。つまり地層として は安定した層厚できわめて広く分布しているが，中味の 岩相，とくに孔隙率，浸透率の水平方向の変化は著しい のが普通である。これは堆積後起る carbonate rock 特 有の続成作用も手伝って局地的飞複雑な孔隙率・浸透率 の変化が見られることが多い。このことは石网岩貯留岩 の中では余り長距離の石油の水平移動は想像できないこ とを意味する。現にカタールのデュカン油田はカタール 半島の大背斜構造の西側の肩にある小さな背斜構造であ り，大背斜構造には石油がない。つまり石油はもっと上 方のカタール背斜の頂部へ移動することなくこの肩で止 ってしまった観がある。また，石灰岩油層の油田の油分 飽和率が減ずる縁辺部では孔隙率・浸透率が急激に減少 する現象も間々見られるのである。

石灰岩油層を見ていると，孔吵率・浸透率，とくに浸 透率の微妙な減少が石油をトラップする要因になってい
るのではないかと思われる節が多い。これがクエイトの ブルガン油田やアラビア石油のカフジ油田のように, ク リーン・サンドの油層が今だに㕃大な带水層に支壳られ ているのとは全くちがう点である。

このように石灰岩の中で微妙な浸透率の変化がトラッ プを形成するチャンスを作ると想像すれば，上に述べた カタールの空白地域にも層位封鎖のチャンスはまだまだ 残されていると想像できるのである。そしてアブダビに 比して一見埋蔵量密度が薄いのは, これらの層位封鎖に よる集油の埋蔵量が末だに隠されているかも知れないの である。

そしてこのかくされた層位封鎖の可能性はカタール海 域のみならず全世界のいわゆる既探鉱地域内においても まだまだあると考える。

さて，問題はこのようにかくされた純然たる層位封鎖 を挆し出すためには，いかなる方法で探鉱にアプローチ したら良いかといらことである。この方法に対する良い 解決が見出されないため層位封鎖は末だにかくされてい るとも想像できる。

そもそも層位封鎖による集油形態を知るためには，ま ず第 1 に貯留岩たる砂層や石灰岩層の pinch out edge あるいは石灰岩などの中における permeability pinch out edge の輪かくを正確に把握しなければならない。地 質学的にはある程度巨視的に岩層の pinch out の edge の線を描くことのできる場合もあるが，実はこれは明確 な線ではなく，ある幅を持ったゾーンで想像できる程度 である。したがって $2 \sim 3$ 坑の試掘で pinch out edge line が明確に描故るといら性質のものではない。この edge line を明確に把握しょうと思ったら, Geologist が想像した edge の zoneの上に網目状のパターンで数 十坑, 地域が広ければ数百坑の試掘を必要とするである う。背斜構造に掘った試掘とちがう点は, 構造頂部に掘 った場合はその試掘結果は地震探鉱結果等と組み合せて 構造規模を大まかに評価するデータとなり得るのに反 し，上記のような edge lineを探る試掘井はその地点に おける point control のデータとして役に立つだけであ るといら点である。だからこそ多数の試掘, つまり多数 の control point が必要となって来るのである。現に米 国のロッキー・マウンテン地域の層位封鎖による集油形 態を明らかにするために数百坑の坑井を掘った例があ る。

こういら多数の試掘は, とくに海外地域探鉱において はとても経済的には引き合うものではない。

私自身の経験を述べると，前述のカタール石油の探鉱 実施の際に傍から僅かばかり拈手伝いさせて頂いたが， 8 坑の試掘が終った時点で上に述べたようにまだまだ層 
位封鎖が存在する可能性を強く心に抱いていた。しかし これを目標にもっと探鉱を続けなさいとは会社に進言で きなかったのである。何となれば試掘によって層位封鎖 を探すにはその先何坑の坑数によって発見できるか，あ るいは本当にあきらめることができるかメドが立たなか ったからである。も52 坑位で発見するかも知れない し，20坑掘ってもまだ疑問が残るかも知れない。とにか く会社の追加投資の根拠としてはリスクが高すぎたので ある。

もら 1 つ現に私が経験しつつある例はアブダビ海域の 東部でウム・アダルクといら場所である。ここでは最初 ドーム構造の探鉱のつもりで頂部に試掘第 1 坑を掘った ら幸い出油を見たが，第 2 坑の試掘の結果は層位封鎖に よる集油の要素の大きいことがわかって来た。そして現 在第 4 坑まで掘ったが埋蔵量規模は依然として疑問の まま残されている。そうかといってこの先坑井のみで pinch out edge を探っていったら，何坑の探掘井で規模 が把握できるかのメドは仲々立ち難いので弱っている。 後に述べるように特殊な地震探鉱 (High Resolution Seismogram）が有効であることをひたすら願っている のである。

さて上に述べたように，層位封鎖の探釷段階において も，発見した層位封鎖の集油規模をたしかめる探掘段階 においても，もし坑井を掘ることによってのみ解決しよ らとしたら，まず坑数のメドを立てるのは非常に困難で あり，石油会社としてはあまりにもリスクの高すぎる投 資となる。したがってこの方法は層位封鎖探鉱の方法と しては現実的ではない。

しからば何が現実的方法かというと, 地球物理・地質 ・油層工学の技術が互いに密接に結びついて層位封鎖を 探す方向へ向らしか道はないと考える。

まず第 1 に地球物理, 直接的には物理探鉱, とくに地 震探鉱である。従来の地震探鉱は地質構造を把握するた めに記録断面（時間断面）の上で地層から反射したと思 われる波のキックを拾い，これを同一反射面と思われる ものへ対比して行くのが根幹的な仕事であった。別の言 葉でいえばこの反射面と思われる波のキックの横への連 続性を追求することであった。そして坑井に打沙る音波 検層（ソニック・ログ）は地震記録を時間から深度へ転 換する際の媒体である速度に関する情報，つまり速度断 面を得る手段の 1 つして地震探鉱と結びついて来たの である。

ところが層位封鎖を探すための地震探鉱はこれとは全 く根幹を異にする。それは地層からの反射面をとらえて 対比する問題ではなくて, 地層自体の物性を分析する問 題である。つまり地層を構成する岩石およびこれに介在
する流体の物性を分析することである。具体的にいらと porous な岩石が存在するか否か，またできれば pore space に介在する流体がガスか油・水かを把握すること である。このためには地震波の記録の上で波の振幅や波 形の分析が対象となるのである。そしてこれは坑井内の 音波検層が対象としているものときわめて似て来るが， 方法的には音波検層は各地層のフロントにおいて音波の 伝達速度を拾って来るものであるから少々異なる。この ように岩石および流体の物性をチェックするような地震 探鉱の発振源は高周波のものでなくてはならないである う。この意味では最近 High Resolution Seismogram 等と呼ばれる新しいテクニックが緒に着いたようであ る。

さてこのよらな新しい物理探鉱のテクニックを最も有 効に発展させるためには, 従来よりずっと緊密な Geologist の理解と協力とを必要とする。従来の地震探鉱結果 ではコンピューターでプロセスされた記録断面あたりか ら Geologist がタッチし始め, Geologist の作業の主体 は Geophysicist が解釈した土台を受け取って，その上 に地質的な解釈を加えるという，いわば一貫作業の中て の作業工程の受け渡し的な色彩が濃かった。喻えてい らならば陶芸において物理探鉱が作った素焼きの壹に Geologist が釉薬を塗ったり絵を描いていたようなもの である。

新しい物理探鉱のテクニックにおいては，こういう受 渡し的な連熬では不十分である。地震探鉱の原記録むで 戻って波形や振幅が地層の物性の意味する所を分析する ためには, Geologist がこの新しい地震探鉱テクニック を学んで協力する必要がある。それと同時に Geophysicist も地層の物性を石油地質学的に良く理解して分析に あたることが必要である。

とくに両者にとって必要なのは地層の中の流体の物性 に関する理解である。地球物理学执よび地質学が地層あ るいは地殸を対象とする時には，ともすれば岩石しかイ メージとして浮ばぬ嫌いがある。これでは流体を鉱床と する石油鉱床学の本質から遠ざかる傾向がどうしても出 て来る。冒頭に掲げた石油鉱床技術とは全くわかり切っ たことながら，正に流体鉱床を対象とする技術なのであ る。これは一見明白に見えていながら，わかり過ぎてい るためにかえって等閑にされているといら危険を私は時 々感じざるを得ないのである。

次に，この流体鉱休が対象であるといら意味におい て，層位封鎖探鉱においての地質と油層工学との連繫に ついて述べよう。

背斜構造の集油を探鉱する場合にはしばしば地質学的 に構造運動の歴史を分析し，いくつかある背斜構造のど 
れが先に成長し形成されたかといら構造生成の順序を想 定し，そして石油がどの構造へ真先きに移動していった かといら点に流体の移動を結びつけて，集油可能性の優 先順位を考えて来たのである。しかし，この場合石油と いら流体の移動・集積の具体的なメカニズムについて は，卒直にいっていささか大ざっぱな解釈しかして来な かったと思わざるを得ない。例光ば石油が分別的に貯留 岩中を up dip の方へ移動するというのが基本概念のよ らであるが，背斜構造の如く閉鎖系の中で液体が流動す る場合には, up dip に石油が移動すれば同時に置換的に 水が down dip に移動しなければならない。つまり交替 置換といらシステムの中で石油といら流体の動きをとら えなくてはならない。

層位封鎖となると，この置換的な運動の他に，石灰岩 貯留岩などの場合には前にも述べたように浸透率の微妙 な変化が石油をトラップすることも有り得る。この場合 は流体の運動としては閉鎖系ではなくて, 石油・水の間の 相対浸透率の作用によって水は通過しても石油はその場 に残されるといら可能性も考光られる。こうした石油の トラップに関する微妙な条件を前提とした場合には，地 質は単に地層の堆積や構造のみを分析しただけでは層位 封鎖による集油のチャンスを想定することは難かしい。 結局地質時代に和ける地層内の流体の動きそのものにも っと着目することが必要である。このためにはGeologist はもっと油層工学的な概念や知識を導入して, 地質時代 の地層の傾動その他の要因によって流体が貯留岩の中で どらいら動きをして来たかの手掛りを求める必要がある と思う。

これはいらべくして容易でないのは私も自から試みよ らとした経験から良くわかるつもりである。第 1 油層工 学で基本的に用いる流動方程式は，比較的単時間に打い てある程度可視的な流動を前提として立てられたもので ある。これに反し石油の移動・集積は厐大な地質時代と いら長時間の中で平均すると, 瞬間的には恐らく静止と 見做されるほどの微速度で動く流体の動きであるから， これを表わすには油層工学の流動方程式は直接適用はで きないかも知れない。しかし，ある地質時代の時間断面 における流体のありさま，例えば圧力のバランス等の問 題においては静力学的な方程式は利用できるはずであ る。こうした分析について油層工学，つまり Reservoir Engineer の側からも大きな協力をすることが必要であ る。

河井興三（談話）は石油が集積する要因の1つとして 地質時代に护ける地層内の異常高圧個処の変遷をキイと 考觉て打られる模様である。私はこれは非常に興味のあ る着眼点であるる思う。なぜかといらと非常に微速度に
せよ流体が流動を起すためには 2 点間に差圧を生ずると いらことが根本原則だからである。

なお，この異常高圧といら問題は後章に扔いて「自然 地震エネルギーの主要起因」と私は考えているので非常 に興味が深い。

また，本総会において「石油の移動と地層の圧密」の 問題を討論するシンポジゥムが開かれるが，これは流体 の動きを直接に対象とする本当の意味で石油鉱床学の端 緒であり誠に喜ばしいことと思う。

くり返していらと，以上に述べたように層位封鎖の探 鉱へアプローチするためには, 地球物理学・地質学・油 層工学の間の緊密な連携が必要であるということであ る。元来この 3 部門は, 石油の場合, 石油鈗床という 1 つの事象を指向している学問なので互いにバラバラであ る方が扔かしいのである。

\section{2. 自然地震エネルギーの有効利用ならびに 大地震の防止について}

実は今迄述べて来たことは一種の序説であってこれか ら述べることが本論なのである。

この問題は石油探鉱からはなれるが，後に述べるよう に結局はわれわれ石油技術者の問題に帰って来るのであ る。また，それ故にあえて石油技術協会の場に拁いて問 題を提起するわけである。

私は 10 数年前から自然に発生する地震のエネルギーは 全く利用できないものかどうかを考えて来た。というの は石油を初めェネルギー資源に乏しい日本としては，内 蔵する自前のエネルギーとして大きなものは火山と地震 位なものである。とくに地震の場合世界における発生数 の 10 分の 1 程度を一手に引受けている豊富な地震国であ る。しか子何10年置きかに発生する大地震はわが国の人 命と財産とにはかり知孔ない被害を及ぼしており，これ からも及ぼすであろう。

この巨大な破壞的エネルギーを事前に有效に利用し， しかもこのエネルギーを人工的に徐々に解放することに よって大地震の発生自身を防止することができたら，こ れは正に災転じて福となすことになるのである。

これは果して人間の力の及ばない夢のようなことであ ろらか? 実は私は最近段々人間の手の届くところにあ るのではないかと思らょうになって来た。そのきっかけ は従来地震学者達が唱光て来た地震発生に関する仮説に 対する大きな疑問と，米国コロラド州の Rangely 拉よ びデンバーの油田において，水攻法の水圧入がいわば人 工的に地震を起してしまった事実报よび前段に述べた石 油鉱床技術の新しい方向がこの問題解決のアプローチの ために大いに役立つこと等である。 
まず最初に自然地震の発生するメカニズムを考えて見よ ら。これは地震学者の間でもまだ一種の作業仮説であっ て, 丁度石油の集積機構の問題と同様に完全に解明され たわけではない。

ここでは地震学者の各説を1つ1つ紹介はしないが， 地震の発生する原因は，地層の「岡体部分」のみを考兄 る限り次の 2 つにしぼられる。

1）地層内に部分的に生じた力学的歪みが蓄積して, 地層（剛体）の弾性限度を越え破壊点に達した時に 地層に部分的破壊が突然起り地震発生となる。

2）上と同様地層内に部分的歪みが蓄積されるが地層 の弾性限度内において突如解放されるために瞬間的 に弾性反撥を起して地震の発生となる。

大多数の地震学者達は上記1)または2)の仮説，あるい はこれに近いものを考えているようである。ただし火山 活動に直接起因する地震の発生についてはこの際一応考 慮から除外するものとする。

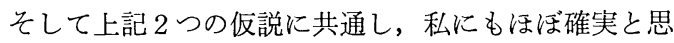
わ机る要素は次の 3 つである。

a ）地震の発生する個所，いわゆる震源は地層内で 「局部的」に歪を受けた場所に限られていること(こ れはわれわれの現実の地震の経験で, 地震波がある 震源から放射状に伝播しているといら事実はまず疑 問なく認めて良いであろらといらことによる。そし てこの「局部的な歪」といらことがメカニズムを考 える上に非常に大切な要素である。)。

b ）地層内の歪エネルギーは瞬間的に，あるいはきわ めて短時間に蓄積したものではなくて，徐々に例兄 ば数10年の時間をかけて蓄積したものである（こ れは，統計上，地震の週期にあらわれて和り，メ力 ニズムの上からも雷の電気エネルギーとは異なり力 学的エネルギーが瞬間的に蓄積されるのは困難であ る。)。

c）地震とは瞬間的なエネルギーの解放である（これ はわれわれが感覚的に地震を経験している事実に照 らしてもまず疑問の余地はないであろら。所が，こ れはまた判り切ったようであるが，実は地震発生の メカニズムを考える上に重要な要素である)。

所が前に述べた地震発生の仮説1)，2）とこの共通 3 要 素a），b），c）とを組み合せるとどうも色々無理が出て 来るように思われる。

まず第 1 に前述の仮説1)，すなわち，力による昰が高 まって破壊点に達すると突如地層の剛体部分が破壊す る，つまり小さい断層を起すようなことを想定した場合 であるが，第 1 の疑問は地層岩石の剛体部分はそんなに 長時間歪の応力を蓄わえていられるものだろうかという
ことである。岩石の中泥岩などはある埋没深度になると 剛体ではなく可塑体であって，歪の力を受ければ最初か ら降伏点を越えてしまい容易に変形したまま歪エネルギ 一なぞは蓄積しない。また硬度の高い砂岩, 石灰岩, 火 成岩なぞは少しでも昰の力を受けると忽ち破壊点を越し て剪断し少しづつずれて行って長い期間歪ェネルギーを 残し蓄積する可能性は少ないと考える。地質的に見た岩 石の露頭に打けるフラクチャリングのようすを観察して もこれは想像される。

第 2 の疑問としては，なるほど大地震の際には現実的 には突然の地表の陷没が起ることもある。例えば1950年 にヒマラヤ地方で起った大地震では長さ $300 \mathrm{~m}$ にわたっ て完全に 5 m の地盤沈下を生じた。これは事実である。 そしてこれは瞬間的な断層による地層ブロックの沈下で ある。

しかしここで重要なのはこのよらな「瞬間的」な地層 ブロックの沈下を地下の剛体がどら受けとめるかるいら ことである。簡単にいえば地下の剛体内に例え $5 \mathrm{~m}$ でも 上から「突然」沈降して来るブロックを受け入れるスペ 一スがあるだろらかということである。たしかに地層中 の泥岩はプラスティックであるが，粘性が高く瞬間的な 地層ブロックの沈下に応じて変形するほど流動性には富 んでいない。地質断面で見る場合は大きな運動量の結果 である褶曲も，大きなずれを持った断層も多くは泥岩の 変形の中に吸収されていることがわかる。しかしこれは 長い地質年代をかけて泥岩が徐々に変形して行ったので あって決して瞬間的に変形したのではない。

ではこの瞬間的な地層ブロックの沈下のメカニズムを どう解釈するかといらと, 地層の剛体部分のみを考えて いたのでは回答は出て来ないと思ら。むしろ地層に介在 する流体部分について考兄なければ解決の道はないと考 えるのでこのことは後で詳しく述べる。

次に前述の 2) の仮説, つまり歪エネルギーの蓄積が 突如解放されて地層が弾性反撥を起して破壊を起すとい う解釈であるが，地層中の硬度の高い岩石でもそれほど 長く弾性の限度内にとどまっているるは思えないのであ る。岩石は薄い鉄板とはちがうのである。厚さ $10 \mathrm{~m}$ 面積 $100 \mathrm{~m}$ 平方の岩石板の自重は 25 万 $\mathrm{t}$ 前後あるのである。 これは分子の凝集力から見ても，自重の何分の 1 かの stress が加わった途端に弾性限度はおろか破壊点をたち まち越してしまうであろうと想像される。つまり仮説1） の時と同じ疑問が起るのである。

また，弾性には体積弾性があって剛体が収縮するよう な stressを受けた場合は体積膨張の弾性反撥力を内蔵 することがある。しかしここでは注意しなければならな いのは，地震エネルギーの震源は「局部的」でなくては 
ならない。つまり地層の剛体のある局部に対し，体積を 収縮させるよらな収斂的 stress が働く必要があるので ある。これは剛体の中の力の方向を考光た場合無理なメ カニズムである。また，この収縮力の想像を許容したと しても，前に述べた岩石の分子凝集力から考光ると，元 の体積まで復原膨張を行ならだけの反撥力が維持される とは思われない。

このメカニズムを考える場合にもやはり剛体の問題で はなくて流体の問題として考光る方が解決の道がある。

地球物理学的にはマントル以下地球の地核までの間に 体積弾性率を考兄ているが，これは地球の中心に向って 収斂的に働く重力による収縮力によるので，全地球的な 規模での体積弾性であって決して局部的なものではな い。

また，前述の仮説 1)，2）のほかに，地球物理学的に は，例壳ば日本列島では太平洋側から北西方日本海に向 って震源点が 45 度の傾斜をもって深くなって行き, 日本 海側では深度 $700 \mathrm{~km} に も$ 達するといらことであるが，私 はこのような深い震源点については依然として大きな疑 問を持っている。深度 $700 \mathrm{~km}$ といえば岩石温度は拱氏 3,000 度に近くなるはずである。こういう温度と圧力下 での岩石の物性は私には良く判らないが，少なくとも 「局部的」に歪エネルギーをトラップし蓄積するのがぞ らいらメカニズムによるのかが大きな疑問なのである。

以上述べたように，地震発生のメカニズムを解釈する のに地層岩石の剛体部分だけを対象とすると仲々解決で きない面があるので，地震発生の拈もな要因は「地層内 の流体にある」といら方向に観点を変えた方が良いので はないかといらのが私の発想である。

ぞうも地球物理学では地球の気圈・水圈を取り扱ら部 門は流体そのものの動きを対象とするが，岩石圈を取り 扱ら部門は地層内の流体をあまり対象としていないよう に思われる。

さて，地層内の流体に着目して地震発生のメカニズム を考劣るに当って前に述べたa)，b)拈よび c )の 3 要素 をもら一度省みて見よう。

つまり a ）地層のある部分にb）局部的に歪エネルギ 一がある程度長年月蓄積して，c）ある瞬間的に解放さ れたものが地震である。このプロセスに地層内の流体の 動きをあてはめて見るる地震の発生機構は次の上らに考 えられる。

地層のあるゾーンに例えばプレートテクトニックス等 の運動により圧力が加えられたとする（具体例について は後に述べる)。この地層の中の貯留岩に介在する流体 (大部分の場合水であるが) がもしも断層等の障壁に囲 まれてトラップされた独立のものである場合, 地層の変
形・圧迫を受けても流体の逃げ場がないので内部圧力は 高まり次第に一種の異常高圧带となって行く。

この異常高圧が限度に来た時, 貯留岩内あるいは隣接 の岩石等に例えば hydraulic fracturing 等を起して突如 として瞬間的に流体（水）は地層圧の低い porous な岩 石の方へ逃げて行く。つまり压力的にい党ば均等化され るわけである。この瞬間的な圧力の均等化現象が地震波 の発生原因となるといら解积である。

この解釈はつまり地震発生の要因が地層の剛体の弾性 に起因するのではなく流体の弾性に起因すると考えたの である。一言でいらならばトラップされた異常高圧带が 地震エネルギーの源であり, 震源であるといら考光方で ある。

どうも剛体弾性よりもこの流体弾性を考皇た方が前に 述べた 3 要素をずっる素直に満足できるように思われ る。

つまり，地層内の「局部的な」歪エネルギーの蓄積と いらことは，剛体内部よりもトラップされた流体ブロッ クについての方が遥かに可能性が高い。事実われわれは 油田地帯においてこらいら局部的な異常高圧帯にしばし ば逢着するのを経験している。そしてこうした異常高圧 帯は局部的にトラップされた現象で地域的に広く拡がっ ている現象ではないこともわかっている。

もっとも, 油田地带の異常高圧帯は現在の所高圧現象 が10年〜20年の間に眼に見光て進行しているわけではな いので地震の起因とはならないであろう。

次歪エネルギーが数 10 年間俆々に蓄積して行く要 素であるが，これる剛体の場合は分子の㠜集力によって 虑大な体積・重力を持つ岩石は降伏点・破壊点が早く来 てしまって弾性エネルギーの蓄積は考光にくい。これに 反し流体の異常高圧ならば徐々に高圧になって内部圧力 のポテンシャルのエネルギーが蓄積することは容易に考 光得るのである。

最後に地震とは瞬間的なエネルギーの解放であるとい ら要素であるが，これも今までに述べたよらに剛体を対 象としていたのでは瞬間的な運動は仲々考光にくい。こ れに対して流体の瞬間的な運動はきわめて可能であり， 現実にわれわれが貯留岩において人工的に hydraulic fracturing を行なら際には，瞬間的にブレークしてかな りの流体が流れることはしばしば経験する所である。

ここに異常高圧現象が現実に地震を惹き起したといら 一種のモデル・サンプルのような興味深い実例を紹介し たい。

それは米国コロラド州の油田におけ水攻法の場合であ る (C.B. Raleigh:「Earthquakes and Fluid Injection」

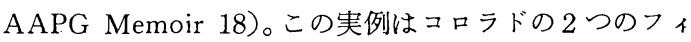


ールドで起っており，1つはデンバーの Rocky Mountain Arsenal 地区であり片方は Uinta Basin Rangely の油田である。

デンバーでは水圧入を行なった処，1962年に地震が始 まり1965年まで連続的に起って1966年水圧入の中止とと もに地震は遠のいた。貯留岩の深度は約 $3,600 \mathrm{~m}$ である。 一方 Rangely 油田では1961年以来水圧入を行なった処 地震が起り始め, 1969年から70年にかけての約 1 年閒に 約1,000回もの地震を記録した。そして 1970 年に 4 本の 水圧入井から逆に水を back flow させ 6 力月続けた所, 地震が終止した。貯留岩深度は1, 800〜3, $600 \mathrm{~m}$ である。

これの著者 C.B. Raleigh が紹介している地震発生の 起因は，貯留岩内の水圧の高まりは一種の引き金で，直 接地震を起した力は既存断層面に平行な剪断 stress と これに垂直な stress との比が変化したためであるとし ている。

これは流体圧はあくまでも引き金で本体の起因は剛体 の stress にあるとしているようであるが，私は前に述 ベた理由で一寸納得しかねる。私は矢張り流体圧が高ま ってこれがブレークして流動したのが本体起因ではない かと解釈している。

しかし, 多少の解釈のちがいはともかくとして, 流体 の異常高圧が地震を誘発していることは否定できない事 実である。そしてこれら 2 地域において流体圧の方が本 体の起因であり，エネルギーではないかという推論を支 持する興味深い事実を列記すると次の通りである。

イ）既存断層付近の水圧入の場合のみ地震が起ったこ と（地震によって既存断層がさらに新しく動いたと いら記録はないので, 私はむしろこの断層は貯留岩 に対して障壁として働き, 水圧入による油層圧維持 の期待以上に圧力が高まって異常高压的トラップを 形成したと解釈する。)。

口）水圧入の結果地層内の圧力が originalの地層圧を 超光てから地震が起り始めている（これは地震の発 生が「異常高圧」に起因していることを示唆してい る。)。

八）水圧入の際, 正常地層圧を僅かに超えた所で hydraulic fracturing を起した例がある。デンバー地 域（これは異常高压に高まった時水が hydraulic fracturing を起してブレークし走り易いことを暗示 している。)。

二）水圧入のピークと地震頻度のピークはかなり精細 に一致している。デンバー（これは異常高圧になっ た現象がストレートに時間的にも地震発生と結びっ いている。)。

ホ）前にも述べたように水王入井から水を back flow
させ異常高王を解消させることにより地震の終熄を もたらしている（これは異常高压から水を抜くこと により地震をとめられるという意味できわめて興味 深い。)。

以上に述べたよらに地震発生エネルギーの本体は異常 高圧帯であるといら解釈に立つと，ここからエネルギー を徐々に取り出して有効に利用するのはあながちわれわ れの手のとどかないことではないことになる。つまりこ の成長しつつある異常高圧帯から流体（水）を坑井を通 じて流出させ, この水流の圧力を利用して水力カタービ ンによる発電を行なうのである。そして深度的にもわれ われの経験する油田に打ける深度範囲が対象になり得 る。

いよいよこの自然地震のエネルギーの利用といら本題 には入るために, われわれの日本を取り巻く地震発生地 帯を対象として考えて見よら。

日本列島の外帯, 太平洋岸に面した海域で北は北海道 十勝沖から房総, 相模灘, 遠州灘, 紀伊半島沖にかけて 一連の地震の巣と呼ばれている震源地の点在が想定され ている。

これら点在する震源地の発生要因としてこの最近の解 釈は例のプレート・テクトニックスの理論によるよらで ある。

このプレート・テクトニックスの説は依然として作業 仮説ではあるが，最近多くの人に支持されている理論で もあるので一応この説に従ってもの事を考えて見ること にする（実は地層圧迫の力の要因は何でも良いのである が。)

この説によると, マントルの上に載った地殼のプレー トは太平洋から西方日本列島へ移動し, 日本海溝の付近 でマントルの対流のために日本列島の地殼の下にもぐり 込もらとしている。この際日本列島の地凯はプレートの 運動の摩擦によって一緒に地下に引きずり込まれようと している。そして太平洋岸の地層は異常な圧迫を受けつ つある。

この日本の太平洋岸ないし沖合が圧迫を受けつつある エスカレーションの状態は決して地質年代の規模のよう な微速ではない。プレートの移動速度は100年間に数米と いら速度なので，われわれの生活年代のスケールでのエ スカレーション状態である。つまりこのプレート速度は 一応大地震の数 10 年週期とマッチした速度といえよう。

さて,このプレート・テクトニックス説によれば日本列 島の太平洋側が一様に圧迫を受けているはずにもかかわ らず，地震が発生する震源は点として散在しており，発 生時間も互いにまちまちである。剛体の破壊や弾性反撥 が地震の原因としたら，剛体の性質上 1 力処が破壊すれ 
ば連鎖反応的に圧迫を受けている全域にわたって破垻が 及んで行く方が普通である。つまり北海道から紀伊半島 までである。

私はそうではなくて，日本の太平洋側全体は圧迫を受 けても地殼の剛体自身は容易に降伏変形して行って歪エ ネルギーの蓄積は残さず，ただ各所に点在してトラップ されている流体のみが異常高圧となってェネルギーを蓄 積し，それが限度に達した時ブレークしてエネルギーを 放出して地震を発生すると解釈する。つまり地震の巣と は「成長しつつある異常高圧帯の巣」と考学るわけであ る。

このよらな異常高圧帯から, 地震の如く瞬間的にエネ ルギーを放出させるのではなく, 徐々に解放して行くた めには坑井を掘り，これを仕上げて水を flow させ，例壳 ば海上に拈いて水カタービンによる発電装置を建設する わけである。排水するのは地層水であるから余り問題な く海上に廃棄できるであろう。

この際 flow による地層圧の減退速度がプレート運動 の地層圧迫による圧力上昇の速度より速ければ，そこで 起り得べき地震を永久に防止することになる。現実的に は異常高圧層に掘り込み，これを仕上げる掘さく仕上技 術にとって困難な点はあろらし，実際仕上げてからの flowによる圧力減退の点からは発電する電力のコストに 対して経済性に疑問が生ずるかも知れない。しかし大地 震の防止の可能性があるるいら面では日本全体のメリッ トとしては測り知れないものがある。 最後に，これら利用すべき震源を求めるのは異常高圧
带の探鉱に他ならないことになる。こうなると探鉣技術 としてはわれわれの石油鉙床技術にぐっと近くなる。

つまり冒頭から前段までは「層位封鎖」の探鉱のため に地球物理学・地質学・油層工学の間の緊密な連携が必 要であることを強調したが，層位封鎖へのアプローチと 異常高圧帯へのアプローチとは流体のトラップといら点 で互いに似た点が多いのである。

したがって，前段に述べた意味での石油鉙床技術発展 の方向は地震の震源地の探鉱への道であり, 地震エネル ギー利用への道, 大地震防止への道に通ずるものと私は 信じたい。

日本列島を取り巻く地震の震源地に対する想定は多く の地震学者および地質学者によって研究され, いわば探 鉱概查は済んでいる観がある。

地震が起ってからの災害を防止するための防災科学は その効果に限度がある。また, 東京のような大都会に対 して大地震の予報をすることは大きなパニック状態を起 すことが明らかなので, 予報科学において研究を進める にもある歯切れの悪さは免がれない。

こういら観点からは, 大地震自体を防止し, このエネ ルギーを有効に活用しょうとする方向に手探りでも良い から何かを進めて見たいと私は願らのである。

まず手始めに鉱床技術者によるグループで基礎研究を 始めることが大切である。これについて石油技術者の諸 賢兄が関心を持ち，何分ご教導賜わるよう心から㹉い 申し上げたい。 